\title{
Vitamin D, Essential Minerals, and Toxic Elements: Exploring Interactions between Nutrients and Toxicants in Clinical Medicine
}

\author{
Gerry K. Schwalfenberg ${ }^{1}$ and Stephen J. Genuis ${ }^{2}$ \\ ${ }^{1}$ Department of Family Medicine, University of Alberta, No. 301, 9509-156 Street, Edmonton, AB, Canada T5P 4J5 \\ ${ }^{2}$ Department of Medicine, University of Calgary, 2935-66 Street, Edmonton, AB, Canada T6K 4C1 \\ Correspondence should be addressed to Gerry K. Schwalfenberg; gschwalf@telus.net
}

Received 9 June 2015; Accepted 12 July 2015

Academic Editor: João Batista T. Da Rocha

Copyright (c) 2015 G. K. Schwalfenberg and S. J. Genuis. This is an open access article distributed under the Creative Commons Attribution License, which permits unrestricted use, distribution, and reproduction in any medium, provided the original work is properly cited.

\begin{abstract}
In clinical medicine, increasing attention is being directed towards the important areas of nutritional biochemistry and toxicant bioaccumulation as they relate to human health and chronic disease. Optimal nutritional status, including healthy levels of vitamin $\mathrm{D}$ and essential minerals, is requisite for proper physiological function; conversely, accrual of toxic elements has the potential to impair normal physiology. It is evident that vitamin D intake can facilitate the absorption and assimilation of essential inorganic elements (such as calcium, magnesium, copper, zinc, iron, and selenium) but also the uptake of toxic elements (such as lead, arsenic, aluminum, cobalt, and strontium). Furthermore, sufficiency of essential minerals appears to resist the uptake of toxic metals. This paper explores the literature to determine a suitable clinical approach with regard to vitamin D and essential mineral intake to achieve optimal biological function and to avoid harm in order to prevent and overcome illness. It appears preferable to secure essential mineral status in conjunction with adequate vitamin $\mathrm{D}$, as intake of vitamin $\mathrm{D}$ in the absence of mineral sufficiency may result in facilitation of toxic element absorption with potential adverse clinical outcomes.
\end{abstract}

\section{Introduction}

The medical literature has achieved general consensus that vitamin $\mathrm{D}$ levels throughout much of the world, as reflected by population measurements of $25(\mathrm{OH}) \mathrm{D}_{3}$ levels, are inadequate [1]. About $2 / 3$ of the population in northern climates are considered deficient with average $25(\mathrm{OH}) \mathrm{D}_{3}$ levels of $67 \mathrm{nmol} / \mathrm{L}$ [2], much below the $100-150 \mathrm{nmol} / \mathrm{L}$ level that has recently been associated with preferred health [3]. There are many papers emphasizing the benefits of supplemental vitamin $\mathrm{D}$ in order to achieve levels that are protective for many diseases $[4,5]$. There has been recent concern expressed, however, that consumption of excessive doses of supplemental vitamin D may pose certain risks and potentially confer harm to individuals. With recognition that vitamin $\mathrm{D}$ intake can also facilitate the uptake of toxic elements, the objective of this review paper is to explore known interactions between vitamin $\mathrm{D}$, essential minerals, and toxic elements in order to provide clinical recommendations regarding the supplemental use of this important vitamin.

This review was prepared by assessing available medical and scientific literature from Medline, as well as by reviewing several books, nutrition and toxicology journals, conference proceedings, government publications, and environmental health periodicals. A primary observation, however, was that limited scientific literature is available on the issue of vitamin $\mathrm{D}$ in relation to essential and toxic elements. The format of a traditional integrated review was chosen as such reviews play a pivotal role in scientific research and professional practice in medical issues with limited primary study and uncharted clinical territory [6].

\section{Vitamin D Adequacy and Safety}

As vitamin D acts epigenetically in the regulation of over 2700 different genes by acting on vitamin $\mathrm{D}$ responsive elements 
[7], it is not surprising that considerable literature confirms the necessity of achieving adequate $25(\mathrm{OH}) \mathrm{D}_{3}$ in order to attain optimal health. A recent article suggests that $25(\mathrm{OH}) \mathrm{D}_{3}$ levels $>30 \mathrm{nmol} / \mathrm{L}$ have significantly lower all-cause mortality than levels $<30 \mathrm{nmol} / \mathrm{L}$ [8]. Levels above $78 \mathrm{nmol} / \mathrm{L}$ are considered beneficial for bone health and maintaining normal parathyroid hormone [9]. Cancer prophylaxis may not be fully realized until levels are over $90 \mathrm{nmol} / \mathrm{L}$ [10]. Benefits in countering infections such as tuberculosis and influenza may require levels of over $100 \mathrm{nmol} / \mathrm{L}$ [11] and levels at or above 120 are associated with the lowest mortality [3].

While there is abundant evidence confirming potential harms associated with deficient vitamin $\mathrm{D}$, as well as much research displaying the enormous benefits of supplementation to replete and maintain adequate vitamin D indices [38], uncertainty has arisen regarding levels that are considered too high. A recent article, for example, showed increased 90day mortality rates in hospitalized patients with preadmission levels of $25(\mathrm{OH}) \mathrm{D}_{3}<50 \mathrm{nmol} / \mathrm{L}$ or $>150 \mathrm{nmol} / \mathrm{L}$ [3]. Such findings have raised concern that levels of $25(\mathrm{OH}) \mathrm{D}_{3}$ greater than $150 \mathrm{nmol} / \mathrm{L}$ may not be optimal. This $\mathrm{U}$ shaped phenomenon of benefit only within a specific range and risk outside of this range has been suggested in other articles as well. The risk for pancreatic cancer, for example, allegedly increases at higher vitamin D levels [39] but on further analysis this finding may have been a statistical artifact due to the chosen cut-off point groupings [40].

The risk of potential harms associated with higher levels, however, is dismissed by others with the contention that $25(\mathrm{OH}) \mathrm{D}_{3}$ levels of $225 \mathrm{nmol} / \mathrm{L}$ can be achieved with ordinary sunlight and are thus considered normal. Furthermore, levels of $<375 \mathrm{nmol} / \mathrm{L}$ have been shown in some research to not result in any evident toxicity [41]. In review, there is insufficient study of supplementary doses of vitamin D which result in $25(\mathrm{OH}) \mathrm{D}_{3}$ levels higher than $150 \mathrm{nmol} / \mathrm{L}$ to make firm conclusions. Just the same, there has been preliminary exploration of pathophysiological mechanisms that might account for potential risks associated with higher $25(\mathrm{OH}) \mathrm{D}$ levels.

\section{Vitamin D and Inorganic Elements}

One point of note is that adequate $25(\mathrm{OH}) \mathrm{D}_{3}$ is associated with improved absorption of essential elements including calcium, magnesium, iron, phosphate, zinc, and copper [12]. What has largely been forgotten, however, is that higher levels of $25(\mathrm{OH}) \mathrm{D}_{3}$ have been linked to enhanced absorption of toxic elements such as aluminum, cadmium, cobalt, and lead as well as radioactive isotopes including cesium and radioactive strontium [12]. It has also been observed in the chick that vitamin D increases zinc and cadmium absorption [42]. Vitamin D has no effect on mercury absorption in the chick intestine but increases cobalt and iron absorption in the presence of low calcium [43]. In children, elevated $25(\mathrm{OH}) \mathrm{D}_{3}$ levels in the summertime are associated with a seasonal increase in blood lead levels via increased intestinal absorption [44]. It is also well recognized that bioaccumulation of such toxic metals in turn appears to disrupt physiological functioning of vitamin D within the body. For example, accrual of lead or cadmium diminishes the activity of vitamin $\mathrm{D}$, by blocking the normal renal synthesis of active 1,25dihydroxyvitamin D [12]. There is also evidence discussed in the literature of myriad adverse effects that various toxic metals including cadmium, lead, mercury, and aluminum can have on normal biological processes including uptake, absorption, and assimilation of assorted essential minerals $[16,17]$ - which may consequently result in health problems. Toxic metals themselves can also accrue in various tissues and have been directly linked to various adverse health outcomes [45-47]. Table 1 provides an overview of the complex interaction between vitamin $\mathrm{D}$ and various inorganic elementsboth required minerals and toxic metals.

The question therefore arises as to whether the alleged rise in morbidity and mortality associated with elevation of $25(\mathrm{OH}) \mathrm{D}_{3}(>150 \mathrm{nmol} / \mathrm{L})$ may be, in part, associated with the increased accumulation of toxic metals-a common concern in contemporary society [48]. To the authors' knowledge, however, no studies have been done to date which measure accrued levels of toxic metals in population groups in direct relation to $25(\mathrm{OH}) \mathrm{D}_{3}$ levels. One of the challenges with the assessment of this hypothesis is that much of the reported biomonitoring of toxic elements in population groups has been confined to unprovoked blood or urine levels of toxicants-which often underestimate the body burden. Most toxic elements and compounds tend to sequester in tissues and may not be evident on blood or urine testing [49]. Lead, for example, may be abundant in bone and brain where it tends to accumulate, with potentially little evidence of such accrual with blood or urine testing [50].

It is also evident that vitamin D does not act solely in isolation. Impaired vitamin D functioning and insufficient levels of essential minerals can have synergistic and cumulative adverse action on biological function with significant pathophysiological impact. For example, vitamin D metabolism is dependent on sufficient magnesium as a cofactor for vitamin $\mathrm{D}$ to bind to its transport protein and for this vitamin to convert into the active form via hydroxylation in renal and hepatic sites [51]. Furthermore magnesium deficiency may upregulate the $24(\mathrm{OH})$ ase enzyme in the kidney resulting in catabolism of active vitamin D [51]. Insufficiency of magnesium has been associated with many adverse clinical effects including depression [52], anxiety [53], and cardiac problems [54] and has recently been found to be associated with impaired immune function [55] and to inversely affect C-reactive protein [56]. It is estimated that more than $68 \%$ of US adults are consuming levels of magnesium below the recommended daily allowance (RDA) [57]. Factors that may enhance magnesium deficiency, states such as accrued toxic metals possibly resulting from elevated vitamin $D$ in the absence of sufficient minerals, may thus have an impact on metabolic function.

Furthermore, any determinant such as accrued toxic metals that would exacerbate zinc deficiency also has a potential detrimental impact on physiological function. Along with iron, boron, manganese, and copper, the essential mineral zinc is important as a cofactor in bone health. Specifically, zinc facilitates bone formation by stimulating the 


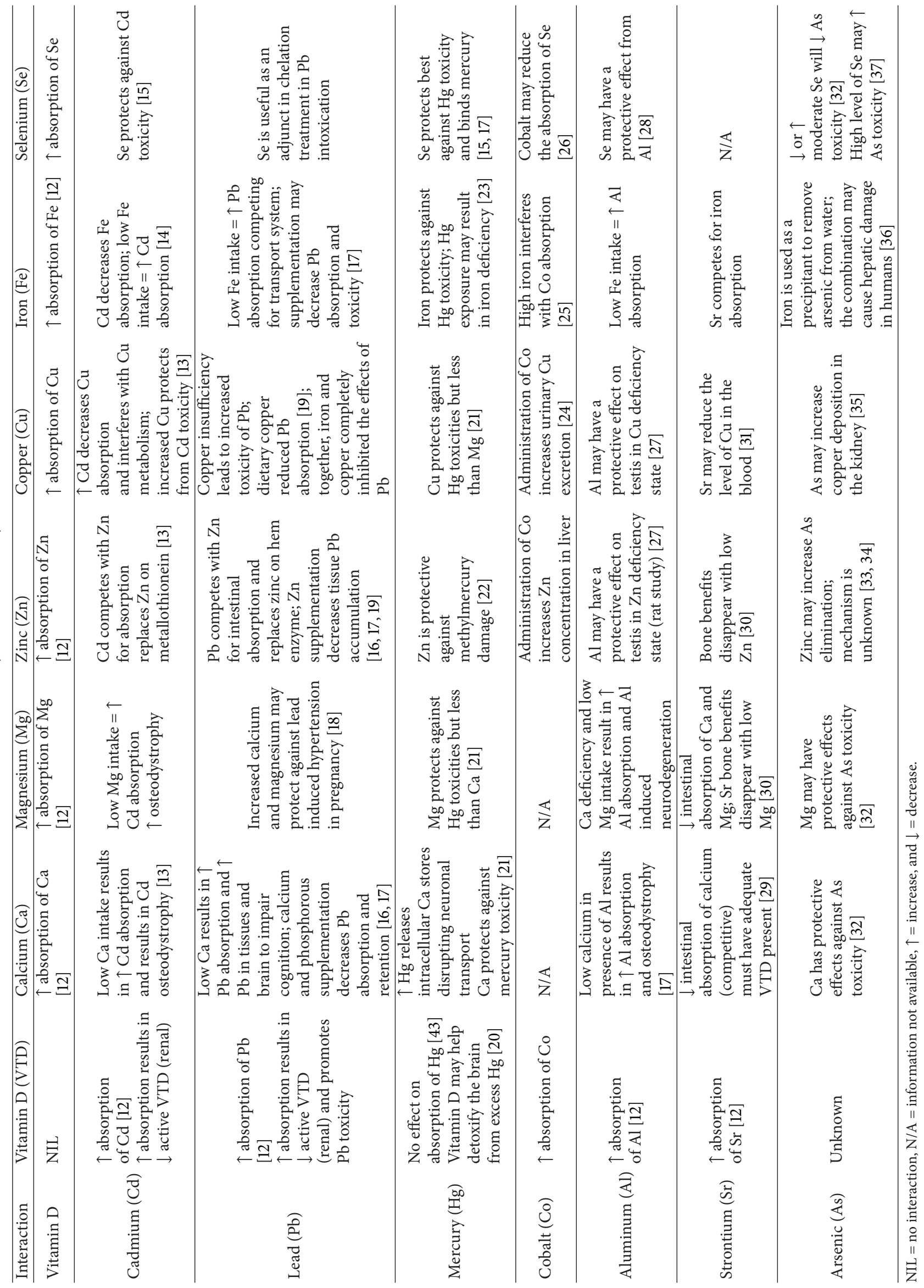


TABLE 2: Vitamin D levels achieved in 2 studies done at northern latitudes.

\begin{tabular}{lcc}
\hline & Number & Percentage \\
\hline (1) Higher latitude statistics for high levels of $25(\mathrm{OH}) \mathrm{D}_{3}, N=1430[2]$ & 15 & $1 \%$ \\
Number of patients with $>150 \mathrm{nmol} / \mathrm{L}$ of $25(\mathrm{OH}) \mathrm{D} 3$ & 315 & $22 \%$ \\
Number of patients with $>100 \mathrm{nmol} / \mathrm{L}$ of $25(\mathrm{OH}) \mathrm{D} 3$ & 300 & $21 \%$ \\
Number of patients with ideal levels $100-150 \mathrm{nmol} / \mathrm{L}$ & 6 \\
(2) Nursing home study using $2000 \mathrm{IU}$ daily of vitamin $\mathrm{D}_{3}$ for $>5$ months, $N=68[63]$ & 54 & $9 \%$ \\
Number of patients with $>150 \mathrm{nmol} / \mathrm{L}$ of $25(\mathrm{OH}) \mathrm{D} 3$ & 48 & $78 \%$ \\
Number of patients with $>100 \mathrm{nmol} / \mathrm{L}$ of $25(\mathrm{OH}) \mathrm{D} 3$ & $71 \%$ \\
Number of patients with ideal levels $100-150 \mathrm{nmol} / \mathrm{L}$ & & \\
\hline
\end{tabular}

${ }^{*}$ All levels achieved in these patients were well below $375 \mathrm{nmol} / \mathrm{L}$ where side effects have been reported.

osteoblast [58]. While the average daily intake of zinc is considered to be only $46-63 \%$ of the RDA, various toxic metals have a detrimental impact on zinc uptake into the body (Table 1). Additionally a study on mineral content of foods has found that more than $80 \%$ of Americans do not achieve the RDA or the estimated safe and adequate daily dietary intake of calcium, magnesium, copper, zinc, and iron. The result of such widespread deficiency may be increased risk of toxic element absorption [59].

The complex interaction between the essential element calcium, vitamin $\mathrm{D}$, and toxic metals is also evident in various reports from the literature [Table 1]. While no more than $800 \mathrm{mg}$ of calcium a day may be required when vitamin $\mathrm{D}$ levels are adequate, the typical diet in North America may be inadequate to supply even this limited amount [60]. Furthermore, as is noted in Table 1, toxic metals may impair calcium uptake resulting in deficiency states. While much recent attention has been devoted to the finding that excess calcium intake may actually cause harm, increasing the risk of myocardial infarction by $31 \%$ and stroke by $20 \%$ [61], it is important to remember that sufficiency of calcium is required for normal physiological function, a clinical state that may be compromised by vitamin $\mathrm{D}$ insufficiency or toxic metal bioaccumulation.

\section{Vitamin D Supplementation}

Adequate sun exposure in warmer climates or consumption of vitamin D containing foods such as fatty seafood in northern areas has traditionally been the preferred means to achieve adequate vitamin $\mathrm{D}$ status. However, higher latitudes experience ultraviolet B sunlight intensities that are too weak for extended periods to induce sufficient vitamin D skin synthesis. Furthermore, insufficient consumption of vitamin $\mathrm{D}$ containing foods frequently occurs because of dietary preference, or avoidance because of concern about toxicant accrual in foods such as mercury in fish. As a result, vitamin D supplementation is being encouraged from many sources as a means to secure adequate intake in order to maintain optimal biological functioning.

With adequate sunlight and food consumption, it appears that there are natural mechanisms to secure preferred vitamin $\mathrm{D}$ levels and to prevent excessive bioaccumulation. With sun exposure, for example, enzyme downregulation appears to occur as higher levels are achieved so that diminished vitamin $\mathrm{D}$ skin production, absorption, and assimilation occur [62]. This inherent protective approach, however, may not be evident with supplemental intake of isolated vitamin D ingestion. With supplementation particularly for populations living in more northern latitudes, how does one secure optimal vitamin $\mathrm{D}$ levels in clinical settings without exceeding healthy levels?

Just as one might measure specific indices such as hemoglobin or potassium levels in patients inclined to be low in these biochemical markers, monitoring of individual $25(\mathrm{OH}) \mathrm{D}$ levels in clinical settings is the preferred way to secure an optimal vitamin $\mathrm{D}$ status in individual patients. As there is variation in response to vitamin $\mathrm{D}$ supplementation as a result of factors such as weight and toxicant levels that influence uptake and absorption of vitamin $\mathrm{D}$, measurement is the only way to confirm optimal vitamin D status, to ensure compliance with instructions, and to preclude excessive or dangerous levels. While there have been many studies that confirm the benefits of vitamin D supplementation in specific groups $[4,5]$, there has been a paucity of studies that actually measure individual levels in population groups after a specific level of supplementation.

The varied response to specific levels of vitamin D supplementation is evident in one such study-a nursing home study supplementing with 2,000 IU daily for more than 5 months (Table 2). The residential population with an average age of $80.7(N=68)$ achieved an average 25(OH)D level of $119.3 \mathrm{nmol} / \mathrm{L}$ with this level of vitamin $\mathrm{D}$ ingestion [63]. Further analysis of this data reveals that 12 patients or $22 \%$ achieved levels less than $100 \mathrm{nmol} / \mathrm{L}$ but that 6 patients or $9 \%$ reached levels of $>150 \mathrm{nmol} / \mathrm{L}$. At this level of supplementation, about $6 \%$ of patients would not achieve levels considered necessary for good bone health at $78 \mathrm{nmol} / \mathrm{L}$ but only 78\% would have levels between 100 and $150 \mathrm{nmol} / \mathrm{L}$. It appears that about 4000 IU of vitamin D might be required to allow a significant portion of the population to achieve the desired 100-150 nmol/L. With this level of supplementation, none of the participants would reach a commonly accepted dangerous $25(\mathrm{OH}) \mathrm{D}$ level of $>375 \mathrm{nmol} / \mathrm{L}$.

In another study (Table 2) of the general population $(N=1430)$ at a northern latitude [2], projections were made based on average responses to specific levels of vitamin D supplementation. In this report, only $22 \%$ of the 1430 patients 
were found to have levels between 100 and $150 \mathrm{nmol} / \mathrm{L}$. Within the $1 \%$ of patients found to have levels over $150 \mathrm{nmol} / \mathrm{L}$ of $25(\mathrm{OH}) \mathrm{D}_{3}$, more than $73 \%$ admitted to pronounced levels of sun exposure, regular artificial sun tanning at tanning studios, or both. The highest level recorded was $216 \mathrm{nmol} / \mathrm{L}$ in a patient that both had sun exposure and was sun tanning, Once again, none of the participants reached levels anywhere near or $>375 \mathrm{nmol} / \mathrm{L}$.

In addition, a recent risk assessment for vitamin D toxicity with supplemental doses found no evidence of toxicity using 10,000 IU daily for a six-month period [64]. As a result of the evident safety of using considerable supplemental doses of vitamin D, the Institute of Medicine (IOM) has recently raised the maximum allowable amount of vitamin $\mathrm{D}$ to 4000 IU daily with no required monitoring for toxicity [65]. With variation in response to specific doses of supplemental vitamin $\mathrm{D}$, monitoring of $25(\mathrm{OH}) \mathrm{D}$ levels with required dose adjustments appears to be the most effective means to secure adequacy and to preclude excessive levels.

\section{Clinical Implications}

There has been much debate in the medical literature about the preferred level of $25(\mathrm{OH}) \mathrm{D}$, the optimal level of supplementation, and the degree of intake or levels that might be dangerous. In the medical literature as a whole, many researchers suggest that measured levels of $25(\mathrm{OH}) \mathrm{D}$ should ideally remain within the 100 and $150 \mathrm{nmol} / \mathrm{L}$ range [66]. This view is endorsed by the Vitamin D Society as lower levels are associated with inferior human health outcomes and higher levels might have the possibility of increasing risk of morbidity and mortality. As mentioned, some recent information suggests that vitamin $\mathrm{D}$ intake to achieve a minimum level of $120 \mathrm{nmol} / \mathrm{L}$ is associated with the lowest mortality [3], a recommendation that has been adopted by groups such as the "Vitamin D Council" and "Vitamin D Society." A recent Endocrine Society recommendation suggests targeting for a $25(\mathrm{OH}) \mathrm{D}$ level value greater than $75 \mathrm{nmol} / \mathrm{L}$. In order to ensure that individuals "true" $25(\mathrm{OH}) \mathrm{D}$ is greater than $75 \mathrm{nmol} / \mathrm{L}$, they suggest aiming for a value of $100 \mathrm{nmol} / \mathrm{L}$, a level that is not associated with toxicity [67].

Conversely, however, some prominent medical groups have differed in their recommendations. While the IOM (Institute of Medicine) agrees that 4,000 IU of vitamin daily is allowable and nontoxic, the actual recommended daily dose by this group is $600 \mathrm{IU}$ daily [65]. This IOM recommendation has been put into question [68] as a significant statistical error has been identified in the way the recommendation was arrived at [69]. Furthermore, the IOM recommendations have been refuted by a study suggesting that it may take as much as $8800 \mathrm{IU}$ of vitamin D daily to bring $97.5 \%$ of the population to levels of $50 \mathrm{nmol} / \mathrm{L}$ [69].

Because of practical concerns such as expense associated with testing, nonetheless, some have suggested that there is no point determining and following $25(\mathrm{OH}) \mathrm{D}$ measurements, with the rationale that most individuals are low and should simply be taking regular vitamin $\mathrm{D}$ supplementation. But the degree of supplementation will vary based on geographic area, degree of sun exposure, nature of the diet, level of toxicants, and so on. Annual testing has long been suggested for this reason [5]. Accordingly, while it is increasingly suggested that a certain range of $25(\mathrm{OH}) \mathrm{D}$ may be associated with preferred health outcomes, there may be huge differences in the required intake of supplemental vitamin D to achieve a specific $25(\mathrm{OH}) \mathrm{D}$ endpoint. For example, populations at higher latitudes would require significantly more supplemental vitamin $\mathrm{D}$ in order to achieve levels above $100 \mathrm{nmol} / \mathrm{L}$ compared to those living in warm sunny climates. Accordingly, annual biomonitoring of $25(\mathrm{OH}) \mathrm{D}$ levels is suggested when possible as the health benefits and resultant cost savings should far outweigh the expense of annual testing. The savings in healthcare dollars have been estimated to be in the range of 14 billion dollars in Canada [70], 187 billion in Western Europe [71], and 56 billion in the United States [72]. Essentially, it is estimated that the cost of biomonitoring would be about $5 \%$ of the cost savings.

Sufficiency of vitamin D has implications for other essential nutrients as this important vitamin is recognized to interact and maintain physiological function in concert with other vitamins and minerals. As discussed, absorption of essential minerals and toxic metals are all increased with more vitamin $\mathrm{D}$, and insufficient levels of various essential minerals appear to facilitate toxic metal absorption [Table 1]. The majority of Americans, however, receive insufficient magnesium [73] largely due to the processing of foods where magnesium levels are reduced by as much as $400 \%$ [74]. Evidence suggests that intake of other essential minerals is also inadequate in many situations, resulting in a higher risk of toxic metal absorption. Hospitalized patients, for example, are prone to mineral deficiencies, particularly in the intensive care units [75]. Accordingly, in order to achieve an optimal vitamin $\mathrm{D}$ status and to minimize the risk of toxic element accumulation, securing intake of essential minerals through foods or supplementation in addition to adequate vitamin D levels is fundamental to achieving optimal health outcomes.

\section{Conclusion}

Several clinical recommendations are in order based on the presented information from the literature. Population studies across the world report low levels of vitamin D. Lifestyle changes and adequate supplementation are required to achieve optimal $25(\mathrm{OH})$ levels - thought to be about 100 $150 \mathrm{nmol} / \mathrm{L}$. From the studies listed in Table 2, it is evident that, in the average population in a country such as Canada with little natural UVB stimulation for $>6$ months of the year, only $22 \%$ of the population achieve levels to confer all the benefits (bone and nonbone) of vitamin D adequacy. Likewise supplementing with $2000 \mathrm{IU}$ would achieve adequate levels in less than about $78 \%$ of the population. Blood monitoring is recommended on a yearly basis with sufficient supplementation to secure optimal levels $(25(\mathrm{OH}) \mathrm{D}$ levels $>100 \mathrm{nmol} / \mathrm{L})$ as outlined above [5]. Such an approach would realize enormous savings of healthcare resources across the world.

It is important to recognize that vitamin D does not work alone but requires essential minerals to achieve its full benefit. Deficiency of minerals including magnesium, calcium, zinc, and iron is very common as outlined above. Recognizing 
the synergistic action of mineral deficiency with elevated vitamin $\mathrm{D}$ levels on the uptake of toxic elements, adequate intake of minerals needs to be ensured.

It is possible that the concern associated with excessive vitamin $\mathrm{D}$ might be explained by the increased absorption and bioaccumulation of toxic elements. Further study is required to explore this emerging concern. Just the same, efforts to reduce exposure to and accrual of toxic elements such as the diminution of emissions of toxic elements by industry are also indicated. This would reduce contamination by toxic elements in the air we breathe as well as deposition in soil and uptake into consumed foods, thus diminishing the risk of exposure and uptake of toxic metals, regardless of levels of vitamin D and essential minerals.

Finally, there is preliminary evidence that higher morbidity and mortality may be associated with excessively elevated vitamin $\mathrm{D}$ levels. This problem may be exacerbated by a deficiency of essential minerals, potentially resulting from inadequate dietary intake or the result of accumulated toxic elements. Therefore, efforts to secure mineral adequacy and to avoid toxic metal exposure and avoidance of potentially excessive vitamin D intake are suggested.

\section{Key Points}

(i) Vitamin D sufficiency as reflected by a $25(\mathrm{OH}) \mathrm{D}$ level of about $100-150 \mathrm{nmol} / \mathrm{L}$ may be an optimal clinical endpoint, although controversy remains over the ideal level. Taking into account the vast number of population studies, in both temperate and equatorial climates, population levels are quite low in many jurisdictions and supplementation is recommended to achieve optimal levels.

(ii) The IOM daily recommendation of 600 IU of vitamin D3 for adults $<70$ years old would not achieve these preferred levels in more than $50 \%$ of people and thus the IOM recommendation has been called into question as outlined above.

(iii) Sufficiency of essential minerals is necessary to prevent bioaccumulation of toxic elements and to enhance activation of vitamin D related proteins.

(iv) Excessive vitamin D intake may have detrimental effects, perhaps by enhancing the absorption of toxic elements.

(v) Levels of vitamin D supplementation required to reach optimal endpoints will vary depending on myriad factors and thus a single recommended dose for all may not be an optimal approach to secure vitamin $\mathrm{D}$ adequacy.

\section{Conflict of Interests}

There is no conflict of interests.

\section{References}

[1] M. F. Holick and T. C. Chen, "Vitamin D deficiency: a worldwide problem with health consequences," The American Journal of Clinical Nutrition, vol. 87, no. 4, pp. 1080S-1086S, 2008.

[2] S. J. Genuis, G. K. Schwalfenberg, M. N. Hiltz, and S. A. Vaselenak, "Vitamin D status of clinical practice populations at higher latitudes: analysis and applications," International Journal of Environmental Research and Public Health, vol. 6, no. 1, pp. 151-173, 2009.

[3] K. Amrein, S. A. Quraishi, A. A. Litonjua et al., "Evidence for a U-shaped relationship between prehospital vitamin D status and mortality: a cohort study," Journal of Clinical Endocrinology and Metabolism, vol. 99, no. 4, pp. 1461-1469, 2014.

[4] G. Schwalfenberg, "Not enough vitamin D: health consequences for Canadians," Canadian Family Physician, vol. 53, no. 5, pp. 841-854, 2007.

[5] M. F. Holick, "The vitamin D epidemic and its health consequences," Journal of Nutrition, vol. 135, no. 11, pp. 2739S-2748S, 2005.

[6] M. P. Dijkers, "The value of traditional reviews in the era of systematic reviewing," American Journal of Physical Medicine \& Rehabilitation, vol. 88, no. 5, pp. 423-430, 2009.

[7] S. V. Ramagopalan, A. Heger, A. J. Berlanga et al., "A ChIP-seq defined genome-wide map of vitamin $\mathrm{D}$ receptor binding: associations with disease and evolution," Genome Research, vol. 20, no. 10, pp. 1352-1360, 2010.

[8] C. F. Garland, J. J. Kim, S. B. Mohr et al., "Meta-analysis of allcause mortality according to serum 25-hydroxyvitamin D," American Journal of Public Health, vol. 104, no. 8, pp. e43-e50, 2014.

[9] M.-C. Chapuy, P. Preziosi, M. Maamer et al., "Prevalence of vitamin D insufficiency in an adult normal population," Osteoporosis International, vol. 7, no. 5, pp. 439-443, 1997.

[10] M. Chatterjee, "Vitamin D and genomic stability," Mutation Research, vol. 475, no. 1-2, pp. 69-88, 2001.

[11] G. K. Schwalfenberg, "A review of the critical role of vitamin $\mathrm{D}$ in the functioning of the immune system and the clinical implications of vitamin D deficiency," Molecular Nutrition and Food Research, vol. 55, no. 1, pp. 96-108, 2011.

[12] J. Moon, "The role of vitamin D in toxic metal absorption: a review," Journal of the American College of Nutrition, vol. 13, no. 6, pp. 559-564, 1994.

[13] H. G. Petering, "Some observations on the interaction of zinc, copper, and iron metabolism in lead and cadmium toxicity," Environmental Health Perspectives, vol. 25, pp. 141-145, 1978.

[14] A. S. Saljooghi and S. J. Fatemi, "Cadmium transport in blood serum," Toxicology and Industrial Health, vol. 26, no. 4, pp. 195201, 2010

[15] U. Lindh, A. Danersund, and A. Lindvall, "Selenium protection against toxicity from cadmium and mercury studied at the cellular level," Cellular and Molecular Biology, vol. 42, no. 1, pp. 39-48, 1996.

[16] R. A. Goyer, "Nutrition and metal toxicity," The American Journal of Clinical Nutrition, vol. 61, no. 3, supplement, pp. 646S650S, 1995.

[17] R. A. Goyer, "Toxic and essential metal interactions," Annual Review of Nutrition, vol. 17, pp. 37-50, 1997.

[18] E. B. Dawson, D. R. Evans, R. Kelly, and J. W. Van Hook, "Blood cell lead, calcium, and magnesium levels associated with pregnancy-induced hypertension and preeclampsia," Biological Trace Element Research, vol. 74, no. 2, pp. 107-116, 2000. 
[19] O. A. Levander, "Lead toxicity and nutritional deficiencies," Environmental Health Perspectives, vol. 29, pp. 115-125, 1979.

[20] E. Garcion, N. Wion-Barbot, C. N. Montero-Menei, F. Berger, and D. Wion, "New clues about vitamin D functions in the nervous system," Trends in Endocrinology and Metabolism, vol. 13, no. 3, pp. 100-105, 2002.

[21] C. B. Singh and S. P. Singh, "Protective effects of $\mathrm{Ca}^{2+}, \mathrm{Mg}^{2+}$, $\mathrm{Cu}^{2+}$, and $\mathrm{Ni}^{2+}$ on mercury and methylmercury toxicity to a cyanobacterium," Ecotoxicology and Environmental Safety, vol. 23, no. 1, pp. 1-10, 1992.

[22] L. Xu, Y. Wang, B. Qiu, and Z. Wang, “The protective effects of zinc metallothionein against erythrocyte membrane damage induced by methylmercury," Wei Sheng Yan Jiu, vol. 29, no. 2, pp. 80-82, 2000.

[23] A. S. Saljooghi and F. D. Mendi, "The effect of mercury in iron metabolism in rats," Journal of Clinical Toxicology, supplement 3, article 006, 2013.

[24] D. W. Rosenberg and A. Kappas, "Trace metal interactions in vivo: inorganic cobalt enhances urinary copper excretion without producing an associated zincuresis in rats," Journal of Nutrition, vol. 119, no. 9, pp. 1259-1268, 1989.

[25] S. Reuber, M. Kreuzer, and M. Kirchgessner, "Interactions of cobalt and iron in absorption and retention," Journal of Trace Elements and Electrolytes in Health and Disease, vol. 8, no. 3-4, pp. 151-158, 1994.

[26] M. R. Gardiner and H. Nicol, "Cobalt-selenium interactions in the nutrition of the rat," The Australian Journal of Experimental Biology and Medical Science, vol. 49, no. 3, pp. 291-296, 1971.

[27] J. Y. Liu and K. L. Stemmer, "Interaction of aluminum with zinc and copper and its effects on pituitary-testicular axis: a histological study, Biomedical and Environmental Sciences, vol. 3, no. 1, pp. 1-10, 1990.

[28] M. G. Abubakar, A. Taylor, and G. A. Ferns, "The effects of aluminium and selenium supplementation on brain and liver antioxidant status in the rat," African Journal of Biotechnology, vol. 3, no. 1, pp. 88-93, 2004.

[29] F. Rousselet, N. El Solh, J. P. Maurat, M. Gruson, and M. L. Girard, "Strontium and calcium metabolism. Interaction of strontium and vitamin D," Comptes Rendus des Seances de la Societe de Biologie et de Ses Filiales, vol. 169, no. 2, pp. 322-329, 1975.

[30] J. M. Fernández, M. S. Molinuevo, A. D. McCarthy, and A. M. Cortizo, "Strontium ranelate stimulates the activity of bonespecific alkaline phosphatase: interaction with $\mathrm{Zn}^{2+}$ and $\mathrm{Mg}^{2+}$," BioMetals, vol. 27, no. 3, pp. 601-607, 2014.

[31] L. Zeneli and N. Daci, "Strontium and its relationship with trace elements $\mathrm{Mg}, \mathrm{Cu}, \mathrm{Co}$, and Mo in human blood and serum," Toxicological \& Environmental Chemistry, vol. 96, no. 5, pp. 808-813, 2014.

[32] D. Srivastava, R. B. Subramanian, D. Madamwar, and S. J. S. Flora, "Protective effects of selenium, calcium, and magnesium against arsenic-induced oxidative stress in male rats," Arhiv za Higijenu Rada i Toksikologiju, vol. 61, no. 2, pp. 153-159, 2010.

[33] M. A. Peraza, F. Ayala-Fierro, D. S. Barber, E. Casarez, and L. T. Rael, "Effects of micronutrients on metal toxicity," Environmental Health Perspectives, vol. 106, supplement 1, pp. 203-216, 1998.

[34] A. Kumar, A. Malhotra, P. Nair, M. L. Garg, and D. K. Dhawan, "Protective role of zinc in ameliorating arsenic-induced oxidative stress and histological changes in rat liver," Journal of Environmental Pathology, Toxicology and Oncology, vol. 29, no. 2, pp. 91-100, 2010.
[35] X. Cui and R. Okayasu, "Arsenic accumulation, elimination, and interaction with copper, zinc and manganese in liver and kidney of rats," Food and Chemical Toxicology, vol. 46, no. 12, pp. 36463650, 2008.

[36] V. R. Mohan Chandrasekaran, I. Muthaiyan, P.-C. Huang, and M.-Y. Liu, "Using iron precipitants to remove arsenic from water: is it safe?" Water Research, vol. 44, no. 19, pp. 5823-5827, 2010.

[37] H.-J. Sun, B. Rathinasabapathi, B. Wu, J. Luo, L.-P. Pu, and L. Q. $\mathrm{Ma}$, "Arsenic and selenium toxicity and their interactive effects in humans," Environment International, vol. 69, pp. 148-158, 2014.

[38] M. F. Holick, "Vitamin D: a D-lightful solution for health," Journal of Investigative Medicine, vol. 59, no. 6, pp. 872-880, 2011.

[39] R. Z. Stolzenberg-Solomon, E. J. Jacobs, A. A. Arslan et al., "Circulating 25-hydroxyvitamin D and risk of pancreatic cancer: cohort consortium vitamin D pooling project of rarer cancers," The American Journal of Epidemiology, vol. 172, no. 1, pp. 81-93, 2010.

[40] L. L. Baggerly and C. F. Garland, "Vitamin D and pancreatic cancer risk-no U-shaped curve," Anticancer Research, vol. 32, no. 3, pp. 981-984, 2012.

[41] R. Vieth, "Vitamin D supplementation, 25-hydroxyvitamin D concentrations, and safety," The American Journal of Clinical Nutrition, vol. 69, no. 5, pp. 842-856, 1999.

[42] N. A. Worker and B. B. Migicovsky, "Effect of vitamin D on the utilization of zinc, cadmium and mercury in the chick," The Journal of Nutrition, vol. 75, pp. 222-224, 1961.

[43] T. Masuhara and B. B. Migicovsky, "Vitamin D and the intestinal absorption of iron and cobalt," The Journal of Nutrition, vol. 80, pp. 332-336, 1963.

[44] F. W. Kemp, P. V. S. V. Neti, R. W. Howell, P. Wenger, D. B. Louria, and J. D. Bogden, "Elevated blood lead concentrations and vitamin D deficiency in winter and summer in young urban children," Environmental Health Perspectives, vol. 115, no. 4, pp. 630-635, 2007.

[45] R. A. Bernhoft, "Cadmium toxicity and treatment," The Scientific World Journal, vol. 2013, Article ID 394652, 7 pages, 2013.

[46] J. R. Cannon and J. T. Greenamyre, “The role of environmental exposures in neurodegeneration and neurodegenerative diseases," Toxicological Sciences, vol. 124, no. 2, pp. 225-250, 2011.

[47] S. C. Bondy, "Prolonged exposure to low levels of aluminum leads to changes associated with brain aging and neurodegeneration," Toxicology, vol. 315, no. 1, pp. 1-7, 2014.

[48] Centers for Disease Control and Prevention: Department of Health and Human Services, Fourth National Report on Human Exposure to Environmental Chemicals. Atlanta: Georgia, 2013, http://www.cdc.gov/exposurereport/pdf/FourthReport_ UpdatedTables_Mar2013.pdf.

[49] S. L. Archibeque-Engle, J. D. Tessari, D. T. Winn, T. J. Keefe, T. M. Nett, and T. Zheng, "Comparison of organochlorine pesticide and polychlorinated biphenyl residues in human breast adipose tissue and serum," Journal of Toxicology and Environmental Health, vol. 52, no. 4, pp. 285-293, 1997.

[50] S. J. Genuis and K. L. Kelln, "Toxicant exposure and bioaccumulation: a common and potentially reversible cause of cognitive dysfunction and dementia," Behavioural Neurology, vol. 2015, Article ID 620143, 10 pages, 2015.

[51] A. Zittermann, "Magnesium deficit-overlooked cause of low vitamin D status?” BMC Medicine, vol. 11, no. 1, article 229, 2013. 
[52] M.-L. Derom, C. Sayón-Orea, J. M. Martínez-Ortega, and M. A. Martínez-González, "Magnesium and depression: a systematic review," Nutritional Neuroscience, vol. 16, no. 5, pp. 191-206, 2013.

[53] G. Grases, J. A. Pérez-Castello, P. Sanchis et al., "Anxiety and stress among science students. Study of calcium and magnesium alterations," Magnesium Research, vol. 19, no. 2, pp. 102-106, 2006.

[54] M. Houston, "The role of magnesium in hypertension and cardiovascular disease," Journal of Clinical Hypertension, vol. 13, no. 11, pp. 843-847, 2011.

[55] M. J. Laires and C. Monteiro, "Exercise, magnesium and immune function," Magnesium Research, vol. 21, no. 2, pp. 9296, 2008.

[56] D. T. Dibaba, P. Xun, and K. He, "Dietary magnesium intake is inversely associated with serum C-reactive protein levels: metaanalysis and systematic review," European Journal of Clinical Nutrition, vol. 68, no. 4, pp. 510-516, 2014.

[57] D. E. King, A. G. Mainous III, M. E. Geesey, and R. F. Woolson, "Dietary magnesium and C-reactive protein levels," The Journal of the American College of Nutrition, vol. 24, no. 3, pp. 166-171, 2005.

[58] W. Lutz, M. F. Burritt, D. E. Nixon, P. C. Kao, and R. Kumar, "Zinc increases the activity of vitamin D-dependent promoters in osteoblasts," Biochemical and Biophysical Research Communications, vol. 271, no. 1, pp. 1-7, 2000.

[59] J. A. T. Pennington, B. E. Young, D. B. Wilson, R. D. Johnson, and J. E. Vanderveen, "Mineral content of foods and total diets: the Selected Minerals in Foods Survey, 1982 to 1984," Journal of the American Dietetic Association, vol. 86, no. 7, pp. 876-891, 1986.

[60] L. Steingrimsdottir, O. Gunnarsson, O. S. Indridason, L. Franzson, and G. Sigurdsson, "Relationship between serum parathyroid hormone levels, vitamin D sufficiency, and calcium intake," Journal of the American Medical Association, vol. 294, no. 18, pp. 2336-2341, 2005.

[61] I. R. Reid, "Should we prescribe calcium supplements for osteoporosis prevention?" Journal of Bone Metabolism, vol. 21, no. 1, pp. 21-28, 2014.

[62] M. F. Holick, J. A. MacLaughlin, and S. H. Doppelt, "Regulation of cutaneous previtamin D3 photosynthesis in man: skin pigment is not an essential regulator," Science, vol. 211, no. 4482, pp. 590-593, 1981.

[63] G. K. Schwalfenberg and S. J. Genuis, "Vitamin D supplementation in a nursing home population," Molecular Nutrition \& Food Research, vol. 54, no. 8, pp. 1072-1076, 2010.

[64] J. N. Hathcock, A. Shao, R. Vieth, and R. Heaney, "Risk assessment for vitamin D," The American Journal of Clinical Nutrition, vol. 85, no. 1, pp. 6-18, 2007.

[65] A. C. Ross, J. E. Manson, S. A. Abrams et al., "The 2011 report on dietary reference intakes for calcium and vitamin $\mathrm{D}$ from the Institute of Medicine: what clinicians need to know," Journal of Clinical Endocrinology and Metabolism, vol. 96, no. 1, pp. 53-58, 2011.

[66] M. F. Holick, Textbook-Physiology, Molecular Biology and Clinical Applications, Humana Press, 2nd edition, 2010.

[67] M. F. Holick, N. C. Binkley, H. A. Bischoff-Ferrari et al., "Evaluation, treatment, and prevention of vitamin D deficiency: an Endocrine Society clinical practice guideline," The Journal of Clinical Endocrinology \& Metabolism, vol. 96, no. 7, pp. 19111930, 1911.
[68] G. K. Schwalfenberg and S. J. Whiting, "A Canadian response to the 2010 Institute of Medicine vitamin D and calcium guidelines," Public Health Nutrition, vol. 14, no. 4, pp. 746-748, 2011.

[69] P. J. Veugelers and J. P. Ekwaru, "A statistical error in the estimation of the recommended dietary allowance for vitamin D," Nutrients, vol. 6, no. 10, pp. 4472-4475, 2014.

[70] W. B. Grant, G. K. Schwalfenberg, S. J. Genuis, and S. J. Whiting, "An estimate of the economic burden and premature deaths due to vitamin D deficiency in Canada," Molecular Nutrition and Food Research, vol. 54, no. 8, pp. 1172-1181, 2010.

[71] W. B. Grant, H. Cross, C. Garland et al., "Estimated benefit of increased vitamin D status in reducing the economic burden of disease in western Europe," Progress in Biophysics and Molecular Biology, vol. 99, no. 2-3, pp. 104-113, 2009.

[72] W. B. Grant, C. F. Garland, and M. F. Holick, "Comparisons of estimated economic burdens due to insufficient solar ultraviolet irradiance and vitamin D and excess solar UV irradiance for the United States," Photochemistry and Photobiology, vol. 81, no. 6, pp. 1276-1286, 2005.

[73] A. Moshfegh, J. Goldman, and L. Cleveland, What We Eat in America, NHANES 2001-2002: Usual Nutrient Intakes from Food Compared to Dietary Reference Intakes, USDA Agricultural Research Department, Washington, DC, USA, 2005.

[74] E. S. Ford and A. H. Mokdad, "Dietary magnesium intake in a national sample of US adults," Journal of Nutrition, vol. 133, no. 9, pp. 2879-2882, 2003.

[75] E. Ryzen, P. W. Wagers, F. R. Singer, and R. K. Rude, "Magnesium deficiency in a medical ICU population," Critical Care Medicine, vol. 13, no. 1, pp. 19-21, 1985. 

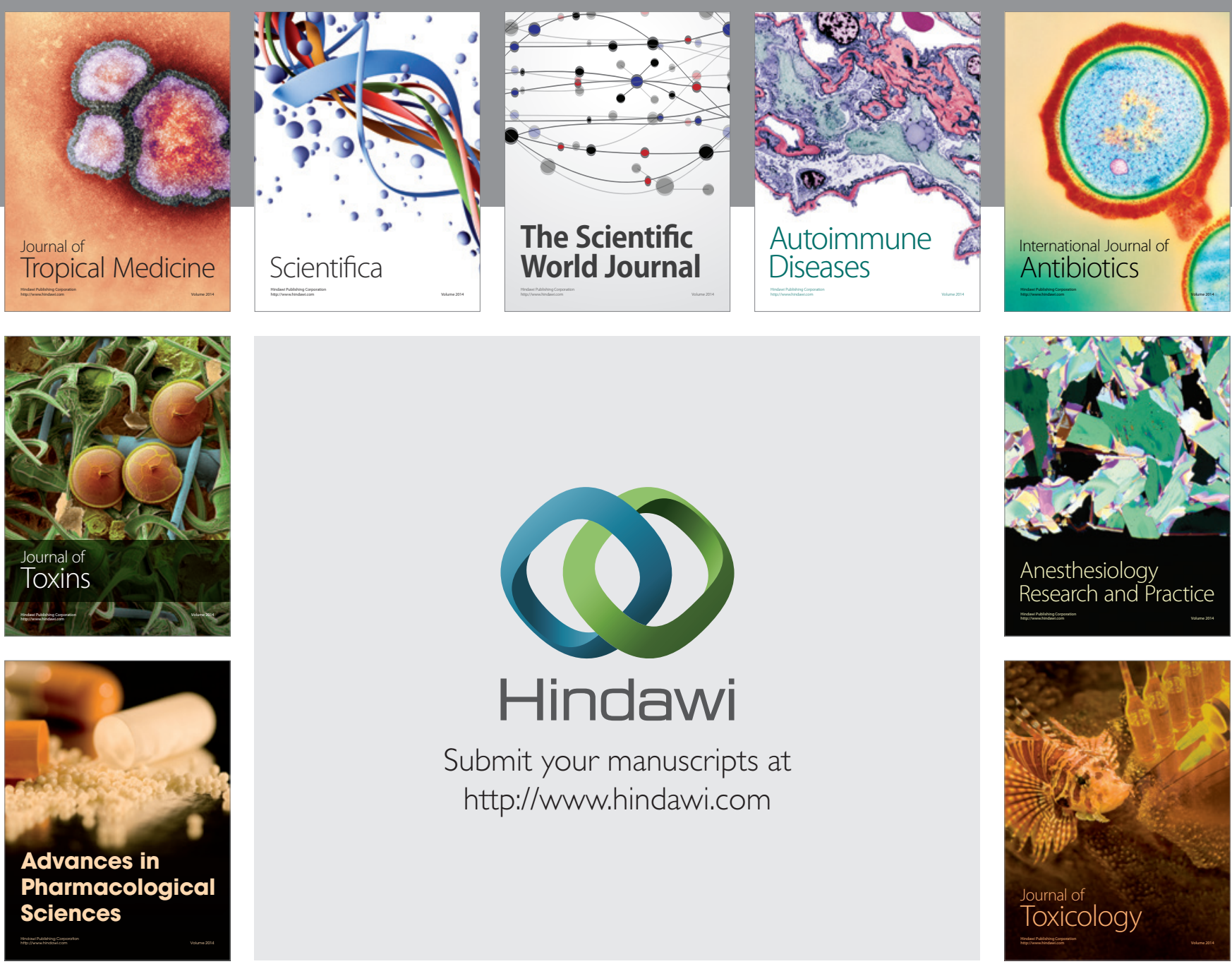

\section{Hindawi}

Submit your manuscripts at

http://www.hindawi.com
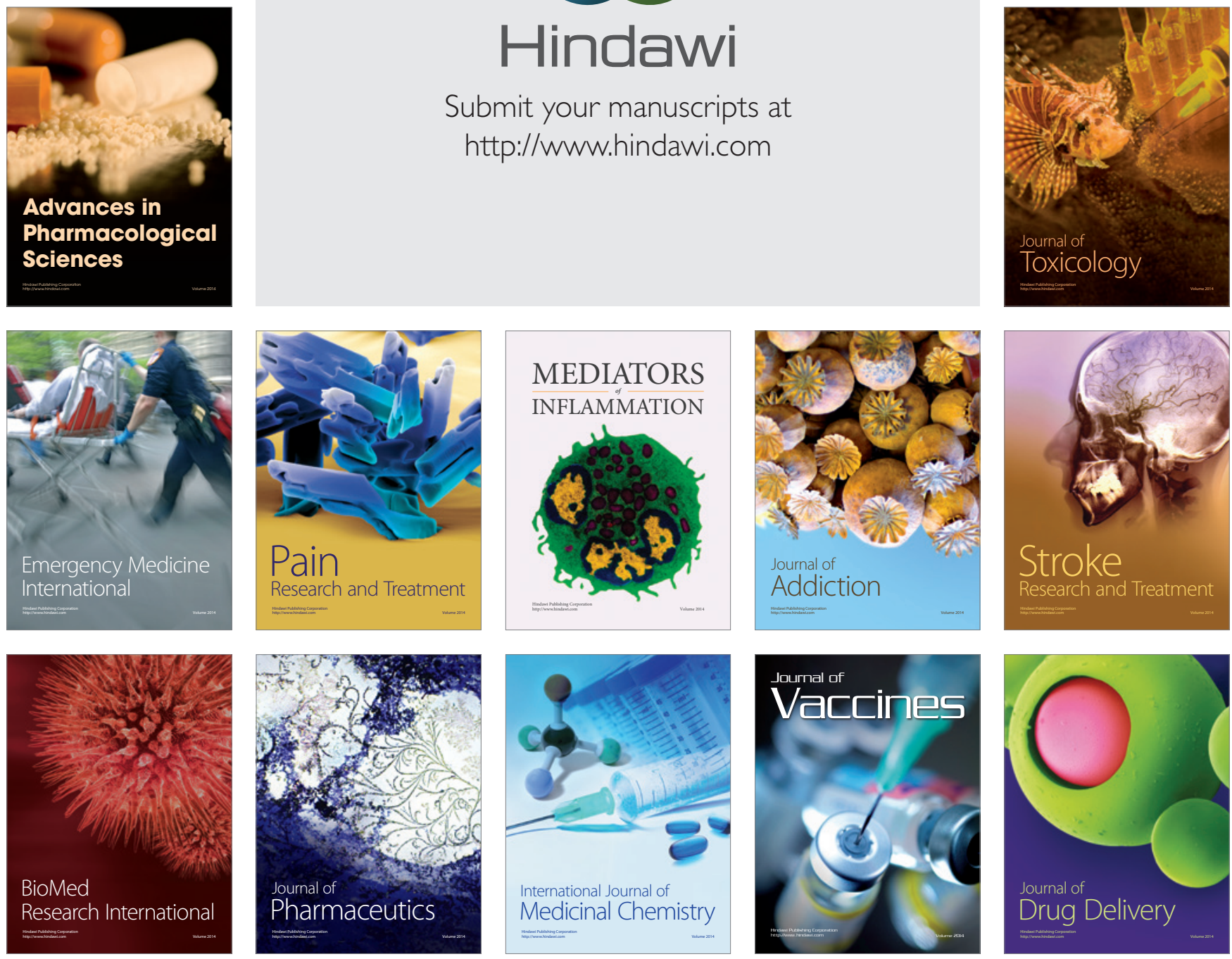